\title{
Criodesidratação do sistema nervoso de um bovino
}

Greiciele Hoffmann Pessoa", Eduarda Cesari, Elisa Coppini Antoniolli, Bruna Alana Pinto, Amanda Ravizoni Webber, William da Silva Dejan, Deise Luiza Mahl, Franciele Oliveira, Daniela dos Santos Oliveira

Instituto de Desenvolvimento Educacional do Alto Uruguai (IDEAU), Caxias do Sul, RS, Brasil

*Autor correspondente

e-mail: greici.pessoa@hotmail.com

\section{Resumo}

O processo de conservação de cadáveres existe desde o antigo Egito, e desde então as técnicas para realização deste recurso estão sendo aperfeiçoadas, já que com a conservação de peças é possível o estudo anatômico dos elementos que constituem um organismo. Objetivou-se, com a criodesidratação, desenvolver uma técnica alternativa que ofereça um custo razoavelmente baixo, de fácil armazenamento e durável, em que se possa reduzir o uso de formol e, assim, diminuir a exposição e toxicidade em relação aos manipuladores, amenizando o risco oferecido ao ambiente. Além disso, objetivou-se manter a conservação e preservação de peças anatômicas o mais fiel possível ao original, ou seja, com a morfologia e características das peças como são nos animais vivos. 0 crânio do animal foi doado por um frigorífico de Erechim/RS para o estudo do material, sendo realizada a técnica de criopreservação que consiste em uma série de congelamentos e descongelamentos do órgão. Para a realização do procedimento de criodesidratação foi utilizado o material retirado de um bovino, do sexo masculino, com aproximadamente 9 meses de idade, pelagem curta, cor preta e branca, destinado ao abate. Foi retirado o cérebro e parte do encéfalo, não sendo possível a obtenção do cerebelo e do tronco encefálico. Para retirada destas estruturas foi utilizado bisturi, faca, cerrote e uma espátula. Após serem coletadas, as peças foram lavadas para a retirada de substâncias indesejadas e, em seguida, submetidas à imersão total no formaldeído a 10\% por 10 dias. Após ser retirado do formol, o material foi lavado novamente e colocado em um recipiente fechado para passar pelos processos de congelamento e descongelamento. Este processo de congelar e descongelar o material foi realizado 15 vezes. 0 sistema nervoso central possui a importante função de organizar os estímulos externos e internos do organismo, sendo o cérebro o principal órgão a desempenhar essa função. A técnica de criodesitratação é um procedimento antigo que utiliza seções de congelamento e descongelamento para 
obter peças anatômicas conservadas sem odor, leves e de fácil utilização em laboratórios de anatomia. 0 congelamento lento da água no interior da célula causa sua expansão e forma cristais de gelo que rompem a membrana plasmática celular, onde repetições do procedimento conseguem maior número de rupturas na parede celular, facilitando a liberação de água do tecido. Com esta técnica é possível um melhor estudo de peças anatômicas, pois a criopreservação é uma técnica de conservação mais durável e mais barata. Foi possível observar que com a criopreservação as peças ficam com uma consistência rígida e esbranquiçada, melhorando a visualização e facilitando assim o estudo anatômico. 